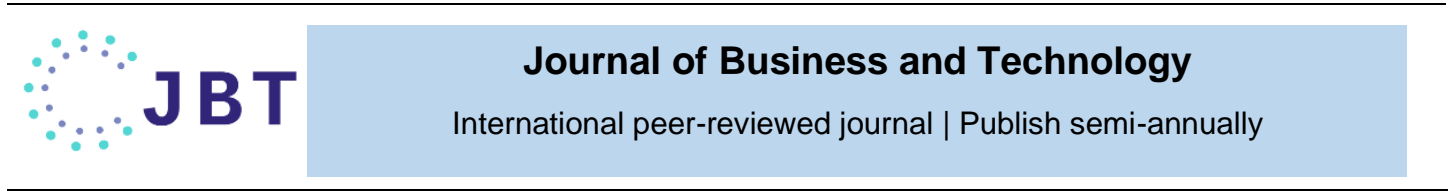

\title{
Instagram Advertisements and Sri Lankan Millennials' Purchasing Intention
}

\author{
Wimalarathna P. A. ${ }^{*}$ and Ranwala R. S. ${ }^{2}$ \\ ${ }^{12}$ Department of Commerce and Financial Management, University of Kelaniya, Sri Lanka. \\ * Corresponding Author: ashvinew@gmail.com
}

\begin{abstract}
This paper aims to identify impact of the Instagram advertisements on purchasing intention of millennials in Sri Lanka using the Technology Adoption Model. Nowadays Instagram is one of the most popular social media platforms, as Instagram has proven to be a strong marketing tool for businesses, which are looking forward to expand their existence and the visibility of their products. It's clear that Instagram isn't just for personal use anymore. The study was conducted utilizing a sample of Instagram users in Western Province including Colombo, Gampaha and Kaluthara districts. Systematic random sampling technique was used to select the sample of 88 Instagram users for the study. Self-administrative questionnaire was used to collect the data from the sample and regression analysis was used to analyze the data and proved hypotheses subsequently. The results of the study revealed that the impact of informativeness, hedonic motivation and economic benefit have a positive impact on purchasing intention, where trustworthiness is not having an impact on purchasing intention of millennials. The inferences of this study can be used by organizations and managers and organizations and managers should be prepared to alter or adapt their Instagram advertising tactics accordingly when targeting the millennials.
\end{abstract}

Keywords: Instagram Advertisements, Millennials, Purchasing Intention, Technology Acceptance Model, Western Province.

\section{INTRODUCTION}

Technological transformation has grown at an unexpected rate over the past decades, especially in online social media platforms. The companies' online existence is necessary and progressively diverse today because global digitalization keeps on increasing and therefore managers introducing social media platforms to the organizations. Online marketing is becoming a standard therefore consumers have moved from reading newspapers and watching TV to mobile platforms, and to reach consumers, companies must stay alert and use the most profitable channels for online marketing and advertising (Pessala, 2016). Social media platforms represent a progressively important vehicle for branded products to communicate with their relevant audience (Murdough, 2009). Social media has become an important platform for global marketing communications and requesting a larger amount of advertising budgets, especially to reach the younger generation. Furthermore, influencer marketing is an emerging trend on Instagram where consumers' purchasing decisions are based on their favourite Instagram models, Twitter personalities, and YouTube stars' advice and guidance. The millions of consumers trusted these influencers so $86 \%$ of consumers purchase products and services based on influencers (Digital Marketing Institute, 2020).

In 2010, Instagram was founded basically for people to share photos and images (Ting, 2015). Since 2013, there's a significant increase in the number of active Instagram users (Lee, 2015) and 800 million people actively used Instagram globally by posting an average of 27.9 images per month (Statista, 
2018a) and 257 minutes spending monthly on it (Brandwatch, 2016). Instagram is one of the fastest-growing social media platforms which has more than 800 million active users worldwide (Leibowitz, 2018) and the most important influence marketing channel over the years with the enormous growth of social media influencers and sponsored posts (Baillis, 2019). Social media users spent longer on Instagram than on Facebook and Twitter, respectively 45 percent and 40 percent longer (Leibowitz, 2017). According to a 2016 social media marketing industry report, usage of Instagram by marketers has expanded from $36 \%$ to $44 \%$ (Stelzner, 2016). Out of the Instagram users $50 \%$ follow at least one business page, while $60 \%$ of users get to know about a product or service from the Instagram, and $75 \%$ of users visit the product's website by looking at an Instagram advertising post (Instagram Business Team, 2016).

A considerable amount of marketing cost over industries is applied to advertising to promote brands (Chi, 2011). In 2018, brands spend \$1 billion for Instagram advertising, and from $\$ 5$ to $\$ 10$ billion in 2022 (Gallagher, 2018). Due to this situation, organizations' managers and academics have placed a great value of advertising on social media such as Facebook, YouTube, LinkedIn, Twitter, and others (Saxena \& Khanna, 2013). Social Network Sites have gained a lot of attention from educators and researchers (Boyd, 2007; Ellison, 2007). Studies conducted on the acceptability of Social Network Sites from the technology acceptance model (TAM) have disclosed that users find these networking platforms uncomplicated to use, flexible to interconnect with, and to find their skills at using the social network sites (Pinho, 2011). According to prior researchers' findings, Instagram advertising has a favourable effect on consumer attitude towards purchasing.

In considering the Sri Lankan context, Sri Lanka is at a lower stage when it comes to social media usage, although computer literacy rates and digital literacy rates are slowly increasing (Department of Census and Statistics, 2019). Even though, Instagram is the third most used app in Sri Lanka (Seven Media Group, 2018), Instagram users in Sri Lanka are quite lower than in other countries. The total advertising audience on Instagram (monthly active users) is 1.10 million, including $31 \%$ female and 69\% male (Digital Sri Lanka, 2019). As Instagram is a trending social network site in the world, companies and firms are now moving towards the advertising on Instagram platform to reach their target audiences.

Based on the above statistics and the previous research findings, it is evident that proper study about the Instagram advertisements is required to be done as it is supported by (Rushworth, 2017). When reflecting literature, much academic research has been done about the attitudes and perceptions of online advertising (Shu \& Chuang, 2011; Jalivand \& Samiei, 2012; Blasco-Arcas, HernandezOrtega, \& Jimenez-Mertinez, 2014; Hsu, 2014). The most of those studies are conducted in developed countries and those findings may not be applicable to a developing country like Sri Lanka. Therefore, researcher has identified the requirement of carrying out research about Instagram advertising in Sri Lankan context. Hence, through the present study researcher intended to identify whether Instagram advertisements are impacting positively on purchasing intention of millennials' according to the Sri Lankan context.

\section{LITERATURE REVIEW}

The Technology Acceptance Model is one of the most used models by researchers to evaluate the acceptance of new technology by new users (Davis, 1989). The TAM provides an important and good theoretical basis for explaining a user's motives towards the use of a technology (Kim, 2006). TAM is one of the most well-known models in information technology acceptance research and so far the existing theoretical approach regarding users' adaptation towards social media (Wirtz, 2016). TAM was acceptable for explaining SNS adoption because of its efficiency to forecast the adoption of any technology and its capability of being extended by the addition of other variables. 
Result of a technology advancement Instagram was introduced and has become a popular technique among companies not only due to its increasing number of users, but also because of its characteristics and the trend of visual content in social media marketing (Neher, 2013; Stelzner, 2016). Instagram strengthens companies' visual content in a storytelling way rather than just pretending textual information. It is based on the idea of sharing to prompt action (Miles, 2014). Miles, (2014) recommends that companies should, as soon as possible, increase their number of Instagram followers to a level that could be considered credible in relation to the company size. Social media platforms have been largely created a new space to customers to find fun and entertainment (Alalwan, 2017). Due to creativity and attractiveness level of social media ads, customers are more attracted towards social media ads (Dwivedi, 2017). Value of the brand can be explained by an advertisement for its customers.

\section{Trustworthiness}

One of the most critical factors affecting for an organization's sustainable success is trustworthiness. The extent to which the consumer recognizes about the brand in the advertisements to be truthful and believable is defined as the advertisement credibility (MacKenzie, 1989). According to Van-Tien Dao, Nhat Hanh Le, Ming-Sung Cheng, and Chao Chen (2014) discussed that trustworthiness has positive effects on consumers' perceived value of social media advertisements and it affects positively towards their online purchase intention. The concept of trustworthiness of advertisements seemed as one of the most important elements of the advertisement value (Saadeghvaziri, 2011; Tsang, 2004). Consumers expect to get relevant information while seeing the advertisements so provide well information about the products and brands is a basic function of an advertisement. It has been proven that advertisements are highly effective in while providing information for consumers; their trustworthiness has always been questioned (Verma, 2014). Advertising trustworthiness can be described by different dimensions such as listening, transparency, trust, responding and assertion (Blackshaw, 2008). The 'trustworthiness can be explained by various measurements. Trustworthiness of source, content of advertisement, message reliability and media reliability (Verma, 2014). Trustworthiness of an advertisement can effect on trustworthiness of the organization itself (Goldsmith, 2000). Trustworthiness relates to the attitude towards advertising (Wang \& Sun, 2010). According to Wang and Sun (2010) trustworthiness is the second powerful predictor for attitudes. Specifically, when it comes to the consumers, they believe online advertising is credible and trustworthy, so consumers tend to have more and more positive attitude towards online advertising. Consumer's perceptions of truthfulness and believability of an advertising is called as credibility in online advertising (Verma, 2014). Believability in source is called as credibility, where most of it is on perceptions of the trustworthiness and knowledge of the information source as clarified by the information receiver (Metzger, 2013). Based on the above literature, there's a positive impact of trustworthiness on purchasing intention.

\section{Informativeness}

Consumers utilize social media to find and exchange information (Bambauer-Sachse, 2011). The informativeness of an advertisement can be defined as the given information of an advertisement can be characterized as "the capacity of the promoting message to consumers regarding the beneficiary by various product and services so the shopper gets the most fulfilment he needs (Ducoffe, 1996). Consumers report that advertising's ability to provide information is the main reason for accepting it (Bauer, 1968; Saadeghvaziri, 2011). Social media advertisements can provide useful information about the brand (Luarn, 2015). It can also include information about specifications of products and technical knowledge about the product attributes (Tafesse, 2015). Due to the several advertising that consumers are exposed 
to, they are consistently searching for informative advertisements that can help them to choose the best product among the alternatives which provides the greatest satisfaction (Ducoffe, Advertising value and advertising on the web, 1996). Instagram strengthens companies' visual content in a storytelling way rather than just pretending textual information. It is based on the idea of sharing to prompt action (Miles, 2014). Information can be defined as the ability of advertising to inform the consumers of product alternatives so that purchases can make satisfaction itself for consumers (Huq, 2015). Information in online advertising called as the informativeness of the advertisement, so advertisement should have the ability to provide updated, timely and easy access of information (Unala, 2011). Information in online advertising is an important aspect in affecting consumer's perception of online advertising. According to Mir's research (2012), advertising as informative is important and very useful for consumers. The extent to which a firm can provide adequate information effects on customer's better purchasing decisions (Haefner, 1990). When a company is not known by customers, make certain possible customers on Instagram may be one of many marketing tools for creating and improving awareness of the company by gaining followers to the business account. Informativeness is one of the most basic function that makes advertisements more valuable. As consumer's rights, they expect to receive correct information while seeing the ads. The informative quality of the information provided in advertisements are strongly related with attitude towards the ad when it broadcasted through traditional media (Ducoffe, 1995). Ducoffe (1996), has mentioned the concept of 'perceived informativeness'. Perceived informativeness of TV advertisements can involve the decision making process of a consumer easier because consumers can not investigate the products offered (Kim, 2010). In present, consumers have the ability to search for peer-to-peer information, accordingly information helps them to enhance their purchase intentions.
Through social media, a brand message could be delivered however customer's trust of a brand or product and their interpretation will depends on the delivery process and the presentation of the advertisement information (Taylor, 2011). Advertisement information is essential for a product when there are many other products in the market (Hamilton, 2009). Hamilton reported that if a brand use an informative advertisement then there could have two possibilities. They are, the advertisement could be used to reach customers and competitors and the advertisement can gain competitor's customers when an advertisement is information oriented so marketers can help to customers to choose a brand when there are enough information is available of the advertisement (Chen, 1999). More the information available of an advertisement for a brand or product, the more it shows the competitiveness than the alternative products (Ducoffe, How consumers assess the value of advertising, 1995). Lee \& Hong (2016) empirically proved the positive relationship between informativeness and consumers' reaction toward social media advertising, and in turn, on their intention to buy the products displayed in the social media advertisements. Based on the above literature, there's a positive impact of informativeness on purchasing intention.

\section{Hedonic Motivation}

The visually dominant Instagram is suitable for hedonic related posts. According to Koufaris, Kambil \& Barbera (2001), whether consumers will turn back to the website page or not depends on their satisfaction of online shopping experience so ultimately it will influence on purchase intention. Advertisements that are motivating will lead to more loyalty towards the brand and to a better purchase intention (Stern \& Zaichowsky, 1991). According to Koufaris, Kambil and Barbera (2001), the satisfaction that customers get from their online shopping experiences indicates to a great extent that the customer will turn back to that website or not (Kim, 2010). Emotional needs of Individual's for an interesting shopping experience is related to 
the hedonic purchasing motivation (Bhatnagar, 2004). Hedonism is related to pleasure rather than completion of task and the shopping experience side which contains of pleasure, curiosity, fantasy, escape (Boedeker, 1995). Hedonic motivation relates to the feelings and the emotional motivation when making impulsive purchases (Baumgartner, 2002). Previous researchers have reported that impulsive purchasing is related with an individual's hedonic motivation (Rook, 1985). Babin Darden and Griffin (1994) define hedonic shopping value awareness of entertainment and emotional value provided through shopping experiences. There are reasons for hedonic motivation for why people go shopping, assuming that there are six elements of hedonic shopping motivation as adventure, social, gratification, ideas, roles and values. Therefore, enjoyment of the shopping experience rather than the usefulness of the product is more important to the consumers with strong hedonic motivation (Arnold, 2003). Buyers who have hedonic motivation receive satisfaction from the experience and the emotions so the main difference between utilitarian and hedonic motivation is consumer's reasons (Mikalef, 2012). Hedonic motivation has a positive relationship than functional motivation according to a previous study about online clothing purchases (Kim, 2007). Female consumer's hedonic shopping motivation will impact on purchase intention (Davis, 2013). Based on the above literature, there's a positive impact of hedonic motivation on purchasing intention.

\section{Economic Benefit}

According to Peltekoglu (2010), it is difficult to find how much every little penny actually contributes to a brand's value. The percentage of the budget accumulated to advertisements affects the value of a brand. However, it's difficult to identify how much each penny contributes to a brand's value. Marketing drives a consumer economy, encouraging goods and services and targeting consumers most likely to become buyers. Keeping existing customers is more cost effective than finding new customers therefore purchase intention is very important fact for marketers (Spreng, 1995). Based on the above literature, there's a positive impact of economic benefit on purchasing intention.

\section{Purchase Intention}

Purchase intention positively influenced by high levels of interaction with posts including "likes" and "shares" (Beukeboom, 2015). Social network sites can positively impact on purchase intention through social media (Beukeboom, 2015; Chew, 2014; Duan, 2008). Purchase intention refers to the probability that a consumer plans or ready to buy a certain brand in the future (Huang, 2011). Chen, (2014) also considered consumer's purchase intention is focusing on the probability of consumer's likeness to purchase goods. Website attitude had a positive effect towards the brand attitude, and it finally transferred in to purchase intention (Hwang, 2011). Consumers' positive attitude towards visual advertising in fashion industry have been found to positively impact brand attitude and intention of purchase (Paerk, 2015). The positive impact of brand attitude and purchase intention has also been mentioned in research related to advertisements of Internet Protocol Television (Shim, 2013). Firm generated content and user generated content on social media were found to positively impact on brand attitude and purchase intention over several brands (Schivinski, 2016). Marketers would create attracting advertising messages and purchase capacity in the mass media in the hope that consumers would become aware of and develop a like to the brand and ultimately purchase the brand. The increased of social network sites has affected on consumer behavior and purchase decisions (Jones, 2015). According to the previous researchers' brand attitude, brand image, brand quality, knowledge about brand, attributes and brand loyalty have a strong impact on purchase intention (Tariq, 2013). Customer satisfaction is influenced by purchase intention (LaBarbera, 1983). Different factors have been found influenced on purchase intention such as prices, availability of information, quality, types of products and discount rates (Alford, 
2002). Product can obtain consumers' intention to purchase the product by an attractive visual marketing technique (Then, 1999). Presentation of a product can result in higher purchase intentions for consumers, such as displayed together with similar items, and from various angles such as front and back (Then, 1999).

Based on the above literature the following conceptual model and hypotheses were derived.

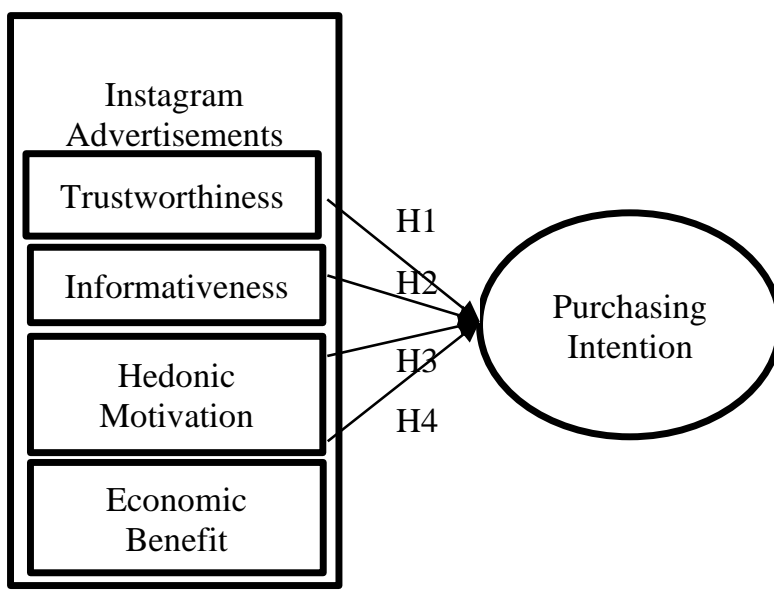

Figure 1: Conceptual Framework

H1 - There's a positive impact of trustworthiness on purchasing intention

H2 - There's a positive impact of informativeness on purchasing intention.

H3 - There's a positive impact of hedonic motivation on purchasing intention.

H4 - There's a positive impact of economic benefit on purchasing intention.

\section{RESEARCH METHODS}

The purpose of this study is to determine the impact of Instagram advertisements on Sri Lankan Millennials purchasing intention. This kind of a research comes under survey research. This study is conducted through a quantitative research method and deductive approach is used. Quantitative approach is used to show relationships between variables, statistical, description and establishing facts. This study conducted in a natural environment which is called as non-contrived setting. Data gathered from each individual Instagram user therefore the unit of analysis is an individual and data collected at a one point of time.

In this study only researchers have focused on millennials out of total population as Sri Lanka age group between 18-24 is the highest number of users (450000 users) which is evaluated at $43.8 \%$. Between $25-34$ its $31.1 \%$ and $9.3 \%$ since 35-44 age group (Digital Sri Lanka, 2019). The millennial age group is between 22 and 38 years, so when it comes to the Sri Lankan context millennials are the highest number of users on Instagram. In the study it focuses on the millennials behavioral attitude towards Instagram advertisements. In Sample frame for this study is Millennial Instagram users within the Western province, Sri Lanka. As the initial sample 100 millennial Instagram users in Western province were selected to the sample due to the time constraint and having no sampling frame. Sampling was done using the systematic random sampling technique where researcher logged into Instagram $22^{\text {nd }}$ of December 2020 for 5 hours form 5.00pm to $10.00 \mathrm{pm}$ and sent the Google Form link of the questionnaire for the 100 followers of the researcher (researcher is having a public Instagram profile where more that 2000 people follow the researcher on Instagram who not friends or relations of the researcher) between 22 years to 38 years, who was online at that time period. However, researcher was able to collect data only from 88 respondents and final sample of the study consist of the 88 sample elements.

The present study evaluates the impact of Instagram advertisements and Sri Lankan millennials purchasing intention. In detail, Instagram advertisement is the independent variable, and it is measured by its components; Trustworthiness, Informativeness, Hedonic motivation and Economic benefit. Further, purchasing intention is the dependent variable. To collect data on above variables, researcher used a self-administrated questionnaire which 
was developed by combing the questions of (Gaber, Wright, \& Kooli, 2019; Karadeniz \& Kocamaz, 2019).

\section{DATA ANALYSIS}

With the selection of the appropriate model, this study used the Descriptive statistics to identify the sample of the study. Further, study used the multiple regression analysis to check the direction, strength, and significance of all variables in the study.

At the beginning of the data analysis, researchers have analyzed the sample characteristics and it is shown in the table 1.

\section{Table 1: Summary of Sample Description}

\begin{tabular}{|l|l|l|}
\hline Demographic Characteristic & Percentage \\
\hline Gender & Male & $39.77 \%$ \\
\cline { 2 - 3 } & Female & $60.23 \%$ \\
\hline \multirow{4}{*}{ Age } & $22-27$ & $87.5 \%$ \\
\cline { 2 - 3 } & $28-33$ & $5.68 \%$ \\
\cline { 2 - 3 } & $34-38$ & $6.82 \%$ \\
\hline \multirow{4}{*}{$\begin{array}{l}\text { Occurrent } \\
\end{array}$} & $\begin{array}{l}\text { Higher } \\
\text { education }\end{array}$ & $38.64 \%$ \\
\cline { 2 - 3 } & Employed & $50 \%$ \\
\cline { 2 - 3 } & Self-employed & $7.95 \%$ \\
\cline { 2 - 3 } & Unemployed & $3.41 \%$ \\
\hline \multirow{5}{*}{ District } & Colombo & $64.77 \%$ \\
\cline { 2 - 3 } & Gampaha & $25 \%$ \\
\cline { 2 - 3 } & Kaluthara & $10.23 \%$ \\
\hline
\end{tabular}

Normality, multicollinearity, heteroscedasticity and autocorrelation were carried out before running the regression analysis in order to confirm that the data fits the basic assumptions of the regression model and all tests proved the fit of the basic model.

As per the table 2, $\mathrm{R}$ square value as 0.538 $(53.8 \%)$ which implies that 53.8 percent of fitness can be observed in the sample regression line. Moreover, it measures 53.8 percent of the total variation in the Purchasing Intention, is explained by independent variables (Trustworthiness, Informativeness, Hedonic Motivation, Economic Benefit) all together. According to the beta values Informativeness is the most impact variables on Purchasing Intention.

According to the table 2, $\mathrm{R}$ square is 0.538 . It implies that $53.8 \%$ of the variance of DV will be explained by the IVs together. According to the model summary table $\mathrm{R}$ square is 0.538 . It implies that $53.8 \%$ of the variance of DV will be explained by the IVs together. Model in the study is significant as it has $\mathrm{P}$ value less than 0.05 .

Table 2: Summary of Regression Analysis

\begin{tabular}{|l|l|l|l|l|}
\hline & \multicolumn{2}{|l|}{$\begin{array}{l}\text { Model } \\
\text { Summary }\end{array}$} & \multicolumn{2}{l|}{ Coefficients } \\
\hline & $\mathrm{R}$ & $\mathrm{R}^{2}$ & $\mathrm{~B}$ & $\mathrm{Sig}$ \\
\hline Model & $.734^{\mathrm{a}}$ & 0.538 & & \\
\hline Trustworthiness & & & 0.070 & 0.532 \\
\hline Informativeness & & & 0.339 & 0.001 \\
\hline $\begin{array}{l}\text { Hedonic } \\
\text { Motivation }\end{array}$ & & & 0.211 & 0.073 \\
\hline $\begin{array}{l}\text { Economic } \\
\text { Benefit }\end{array}$ & & & 0.267 & 0.022 \\
\hline
\end{tabular}

All the independent variables other than the trustworthiness have a significance value less than 0.05. Therefore, all independent variables other than trustworthiness have a positive impact, only on purchasing intention of millennials. According to the statistics the hypothesis about the impact of trustworthiness on the purchasing intention of millennials is not supported where all other hypothesis, impact of informativeness, hedonic motivation and economic benefit on the purchasing intention of millennials are supported. Table 3 summarizes this status of hypotheses testing of the study.

Table 3: Summary of Hypothesis Testing

\begin{tabular}{|l|l|}
\hline Hypotheses & Status \\
\hline $\begin{array}{l}\text { H1- There's a positive impact of } \\
\text { trustworthiness on purchasing } \\
\text { intention }\end{array}$ & Rejected \\
\hline $\begin{array}{l}\text { H2-There's a positive impact of } \\
\text { informativeness on purchasing } \\
\text { intention }\end{array}$ & Accepted \\
\hline $\begin{array}{l}\text { H3-There's a positive impact of } \\
\text { hedonic motivation on purchasing } \\
\text { intention }\end{array}$ & Accepted \\
\hline $\begin{array}{l}\text { H4-There's a positive impact of } \\
\text { economic benefit on purchasing } \\
\text { intention }\end{array}$ & Accepted \\
\hline
\end{tabular}




\section{FINDINGS AND DISCUSSION}

In Sri Lankan context companies and firms budgeted more investments in Instagram platform to market their products and services, although it is needed to investigate that, does Instagram advertisements can really impact on consumers purchasing intention. Furthermore, is it worth to do more investments on Instagram advertisement marketing in Sri Lanka. In this study, the effects of Instagram advertisements on millennials' purchasing intention have been investigated and these ads effects on millennials' purchasing intention have been measured in terms of the sub effects of trustworthiness, informativeness, hedonic motivation and economic benefit of advertisements.

\section{H1 - There's a positive impact of trustworthiness on purchasing intention}

As per the results of Regression analysis, it is confirmed that trustworthiness on Instagram advertisements is not a predictor of purchasing intention. The relationship of trustworthiness and purchasing intention is not significant, therefore the first hypothesis was rejected. According to Sri Lankan context still most people do not trust the things that they see, hear from social media. Especially when it comes to Instagram, when compared to other countries Instagram users are lower in Sri Lanka. Still Instagram is not much popular in Sri Lanka like Facebook, YouTube. According to a survey done by trustpilot.com, less than 3 in 10 consumers said they trusted digital advertising. Targeted ads on social media and sponsored ads on social platforms and websites were viewed by users with a particular scepticism and consumer trust won't be won through new trends and technologies so Instagram also a new trend to Sri Lanka because still it doesn't have a huge audience compared to other social platforms. In this study, researcher only focused on millennials as they are the ones who use Instagram mostly but still millennials also do not trust about Instagram ads.

In contradiction to the findings of present study, previous researchers suggest trustworthiness as a predictor of purchasing intention (Ducoffe, 1991; Carr, 2001). Wang and Sun (2010) found that trustworthiness is the second powerful predictor for attitudes. Specifically, when it comes to the consumers, they believe online advertising is credible and trustworthy, so consumers tend to have more and more positive attitude towards online advertising.

H2 - There's a positive impact of informativeness on purchasing intention.

In the present study, it is found that informativeness of Instagram advertisements is a predictor of purchasing intention as it had a positive impact on purchasing intention of millennials. Information in online advertising is an important aspect in affecting consumer's perception of online advertising. Based on the sig value and the $B$ value of the regression analysis the second hypothesis of the study was accepted. According to Mir, (2012), advertising as informative is important and very useful for consumers. The extent to which a firm can provide adequate information effects on customer's better purchasing decisions (Haefner, 1990).

H3 - There's a positive impact of hedonic motivation on purchasing intention.

Hedonic motivation proved to be a predictor of the purchasing intention of millennials, form the findings of the present study. Hedonic motivation shows a positive and significant impact on purchasing intention and the third hypothesis of the study was accepted. These results are complied with the literature. According to Koufaris, Kambil and Barbera (2001), the satisfaction that customers get from their online shopping experiences indicates to a great extent that the customer will turn back to that website or not. Further, Hedonic motivation relates to the feelings and emotional motivations when making impulsive purchases (Baumgartner, 2002). Previous researchers have reported that impulsive purchasing is related with an individual's hedonic motivation (Rook, 1985).

H4 - There's a positive impact of economic benefit on purchasing intention. 
Findings of the present study reviled that economic benefit is a predictor of purchasing intention of millennials where economic benefit shows a positive and significant impact on purchasing intention. Based on the statistics of regression analysis, the fourth hypothesis was accepted.

Through this research, researcher was able to generate important new perception about a rare topic, specifically, in terms of the Sri Lankan context, which is of benefit to the organisations that utilise or intend to use Instagram advertisements as a marketing communication platform. The study specifically provides valuable insights into the impact of Instagram advertisements on Sri Lankan Millennials 'purchasing intention. According to the findings of the present study, Instagram advertisements have an impact on millennials' purchasing intention. Trustworthiness, Informativeness, Hedonic motivation and Economic benefit have a positive impact on purchasing intention but only trustworthiness on purchasing intention is not significant.

\section{LIMITATIONS AND FUTURE RESEARCH DIRECTIONS}

One of the main findings on marketing on social network sites is that social impact can affect perception of quality and purchase intention, especially for consumers who have less involvement involved in the purchase intention (Chew, 2014).

The current study used 88 as the sample size out of total millennial Instagram users in Sri Lanka. If the sample size was bigger than the used sample, it can be expected some changes in the inferences derived. Therefore, it is recommended for future researchers to use bigger sample than the current study. Very importantly, this study conducted in the context of Sri Lanka only about Millennial Instagram users and it was noted that for a further study it can use not only the millennials but also any age group. Therefore, in future, it can be researched on the impact of Instagram advertisements and Sri Lankan Instagram users' purchasing intention. In this study a single Social Network Site was surveyed, whereas future studies could examine other widely used SNS such as YouTube, Facebook, LinkedIn, and Twitter.

\section{REFERENCES}

Abzari, M. G. (2014). Analysing the effect of social media on brand attitude and purchase intention: the case of Iran khodro company. Procedia - Social and BehavioralSciences, Vol.143,pp.822-826.

Ajzen, I. a. (1980). Understanding attitudes and predicting social behavior. Prentice Hal: Englewood Cliffs, NJ.

Alalwan. (2017). Social media in marketing. A review and analysis of the exsisting literature. telematics and informatics, 34(7) 1177-1190.

Alford, B. L. (2002). The effects of discount level, price consciousness and sale proneness on consumers' price perception and behavioural intention. . Journal of Business Research, 55(9), pp. 775-783.

Arnold. (2003). Hedonic shopping motivations. Journal of Retailing, 79(2), pp.77-95.

Arnold. (2018, January 14). How progressive companies are using Instagram to attract top talent. Retrieved from www.forbes.com:

www.forbes.com/sites/andrewarnold/2018 /01/14/how-progressive-companies-areusing-instagram-to-attract-toptalent/\#32953b8040d0

Bambauer-Sachse, S. a. (2011). Brand equity dilution through negative online word of mouth communication. Journal of Retailing and Consumer Services, Vol. 18 No. 1, pp. 38-45.

Bauer, H. H. (1968). Driving consumer acceptance of mobile marketing: A theoretical framework and empirical study. Journal of Electronic Commerce Research, 6(3), 181.

Baumgartner, H. (2002). Toward a personology of the consumer. Journal of Consumer Research, 29(2,)pp. 286-292. 
Beukeboom, C. K. (2015). Does a virtual like cause actual liking? How following a brand's Facebook updates enhances brand evaluations and purchase intention. Journal of Interactive Marketing, Vol. 32, pp. 2636.

Bhatnagar, A. G. (2004). A latent class segmentation analysis of E-Shoppers. Journal of Business Research, 57(7), pp. 758-767.

Blackshaw. (2008, May, June). New media. Retrieved from https://archive.ama.org/archive/ResourceL ibrary/MarketingManagement/documents/ MMMayJune08Blackshaw.pdf

Blasco-Arcas, L., Hernandez-Ortega, B., \& Jimenez-Mertinez, J. (2014). The online purchase as a context for co-creating experiences. Drivers of and consequences for customer behaviour. Internet Research, Vol. 24 No. 3, pp. 211-242.

Blight, M. R. (2017). Sense of community on Twitter and instagram; exploring the roles of motives and parasocial relationnships. Cyberpsychology, Behaviour, and Social Networking, Vol. 20 No. 5, pp. 314-319.

Boedeker, M. (1995). Optimum stimulation level and recreational shopping tendency. European Advances in Consumer Research,, 2, pp. 372-380.

Bolton, R., Parasuraman, A., Hoefnagels, A., migchels, N., Kabadayi, S., Gruber, T., . . . Solnet, D. (2013). Understanding Generation Y and their use of social media; a review and research agenda. Journal of Service Management, Vol. 24 No. 3, pp. 245-267.

Boyd, D. E. (2007). Social network sites: definition, history, and scholarship. Journal of Computer-Mediated Communication, Vol. 13 No. 1, pp. 210230.

Brahim, S. (2016). The impact of online advertising on Tunisian consumers' purchase intention. Journal of marketing research \& case studies, Vol. 2016, article ID 357783, 13 pages.

Brandwatch. (2016, October 23). Instagram user statistics. Retrieved from www.brandwatch.com: www.brandwatch.com/blog/37-instagramstats-2016

Bronner, F., \& Neijens, P. (2006). Audience experienes of media context and embedded advertising: a comparison of eight media. International Journal of Marketing Research, Vol. 35 No.9,pp. 770-790.

Chen, Q. \&. (1999). Attitude toward the site. Journal of AdvertisingResearch, 39.

Chew, S. a. (2014). Marketing sports products on Facebook: the effect of social influence. Physical Culture and Sport: Studies and Research, Vol. 61 No. 1, pp. 65-73.

Chi, H. (2011). Interactive digital advertising vs virtual brand community. Journal opf Interactive Advertising, Vol. 12No. 1, pp.44-61.

Coleman, L. a. (2012). Technology ease of use through social networking media. Journal of Technology Research, Vol. 3, pp. 1-12.

Colliander, J. M., \& Colliander,Marder, J. (2018). 'Snap happy' brands: increasing publicity effectiveness through a snapshot aesthetic when marketing a brand on Instagram. Computers in Human Behaviour, Vol. 78,pp.34-43.

Davis. (1989). "User acceptance of computer technology: a comparison of two theoretical models. Management Science, Vol. 35 No. 8, pp. 982-1003.

Davis. (1989). Perceived usefulness, perceived ease of use, and user acceptance of information technology. MIS Quarterly, Vol.13No.3,pp.319-340.

Davis. (2013). How gender affects the relationship between hedonic shopping motivation and purchase intentions. Journal of Consumer Behaviour, 13(1), pp. 18-30. 
Department of Census and Statistics. (2019, first six months). Department of Census Statistics. Retrieved from Computer Literacy Statistics- 2019: http://www.statistics.gov.lk/education/Co mputerLiteracy/ComputerLiteracy2019Q1-Q2-final.pdf

Digital Sri Lanka. (2019). Retrieved from DataReportal:

https://datareportal.com/digital-in-srilanka

Djafarova, E. a. (2017). "Exploring the credibility of online celebrities' Instagram profiles in influencing the purchase decisions of young female users",. Computers in Human Behaviour, Vol.68, pp. 1-7.

Duan, W. G. (2008). Do online reviews matter? An empirical investigation of panel data. Decision Support Systems, Vol. 45 No. 4, pp. 1007-1016.

Ducoffe. (1995). How consumers assess the value of advertising. Journal of Current Issues \& Research in Advertising.

Ducoffe. (1996). Advertising value and advertising on the web. Journal of Advertising Research, 36(5), 21-35.

Duffet, R. (2014). Facebook advertising's influence on intention-to-purchase and purchase amongst Millennials.

Dwivedi. (2017). An empirical validation of a unified model of electronic government adoption (UMEGA). Government information quartely, 43(2), 211-230.

Eighmey, J. ( 1997). Profiling user responses to commercial web sites. Journal of advertising research, .

Ellison, N. S. (2007). The benefits of facebook "friends": social capitsl and college students' use of online social network sites. Journal of Computer-Mediated Communication, Vol. 12 No. 4, pp. 11431168.

Evans, N. P. (2017). Disclosing Instagram influencer advertising : the effects of disclosure language on advertising recognition, attitudes, and behavioural intent. Journal of Interactive Advertising, Vol. 17 No. 2, pp. 1-12.

Finin, T. D. (2005). Social networking on the semantic web. The Learning Organization, Vol. 12 No. 5, pp. 418-435.

Fishbein, M. a. (1975). Belief, attitude, intention and behaviour: An introduction to theory and research. AddisonWesley, Reading,MA. .

Gaber, H. R., Wright, L. T., \& Kooli, K. (2019). Consumer attitudes towards Instagram advertisements in Egypt: The role of the perceived advertising value and personalization. Cogent Business \& Management, 6, 1-13.

Gallagher, K. (2018, March 17). The influencer marketing report. Retrieved from www.businessinsider.com: www.businessinsider.com/the-influencermarketing-report-2018-1/?IR=T

Gefen, D. (2010). Inexperience and experience with online stores: the importance of TAM and trust"',. IEEE Transactions on Engineering Management, Vol. 50 No. 3, pp. 307-321.

Geurin, A., \& Burch, L. (2016). Communicating via photographs: a gendered analysis of Olympic athletes' visual self-presentation on Instagram. Sport Management Review, Vol.19 No2,pp. 133145.

Goldsmith, R. B. (2000). The influence of corporate credibility on consumer attitudes and purchase intent. Corporate Reputation Review, Vol. 3. No.

Haefner, R. (1990). Advertising in contemporary society. South western publishing.

Hamilton, S. F. (2009). Informative advertising in differentiated oligopoly markets. International Journal of Industrial Organization, 27, 60-69. 
Helmrich, B. (2016, October 25). Instagram for business; everything you need to know. Retrieved from www.businessnewsdaily.com: www.businessnewsdaily.com/7662instagram-business-guide.html

Hsu. (2014). Understanding online shopping intetion; the roles of four types of trust and their antecedents. Internet Research, Vol. 24 No. 3, pp. 106-139.

Huang, Y. W. (2011). Decision making in online auctions", in Rausch, E. (Ed.), Management Decision. Emerald Group Publishing, Vol. 49 No. 5, pp. 784-800. .

Huq, S. M. (2015). Cutomer's attitude towards mobile advertising in Bangladesh. International journal of business and economic $s$ research, Vol.4, No. 6, 2015, 281-292.

Hutchins, B. (2017, April 10). Why your business needs to use Instagram in 2017 (Infographic). Retrieved from www.socialmediatoday.com: www.socialmediatoday.com/social/busine ss/why-your-business-need-use-instagram2017-infographic

Hwang, J. Y. (2011). Structural effects of cognitive and affective responses to web advertisements, website and brand attitudes , and purchase intentions: the case of casual dining restaurants". International journal of hospitality management, Vol. 30 No. 4, pp. 897-907.

Instagram Business Team. (2016, September 22). Retrieved from https://business.instagram.com/blog/50000 0 -advertisers

Jakarta Globe 2017. (2017, October 23). Retrieved from Jakarta Globe: http;//jakartaglobe.id/news/instagram-45million-users-indonesia-laegest-asiapacific

Jalivand, M., \& Samiei, N. (2012). The impact of electronic word-of-mouth on a tourismdestination choice; testing the theory planned behaviour (TPB). Internet Research, Vol. 22 No. 5, pp. 591-612.

Johnson, L. (2015). How food brands can nail Instagram. Retrieved from www.adweek.com/brand-marketing/heres-how-food-brands-can-nail-instagram165224/

Jones, N. B. (2015). Impact of social media on small businesses. Journal of small Business and Enterprise Development, Vol.22 No. 4, pp. 611-632.

Karadeniz, M., \& Kocamaz, I. (2019). The Effect Of Facebook, Youtube And Instagram Advertisements On Consumers' Buying Behaviours. Turkish Journal of Marketing, 4(3), 298-311.

Khang, H. K. (2012). "Social media research in advertising, communication, marketing and public relations. Journalism and mass comunication, Vol. 89 No. 2, pp. 279-298.

Kim. (2006). Toward an understanding of web-based subscription database acceptance. Jurnal of the American society for Information science and Technology, Vol. 57 No. 13, pp. 1715-1728.

Kim. (2007). Hedonic usage of product virtualization technologies in online apparel shopping. International Journal of Retail \& Distribution Management, 35(6), pp. 502-514.

Kim. (2010). Advertising creativity in Korea: scale development and validation. Journal of Advertising, 39 (2), 93-108.

Kudeshia, C. a. (2017). Social e-WOM: does it affect the brand attitude and purchase intentionofbrands? Management Research Review, Vol.40No.3,pp.310-330.

LaBarbera, P. A. (1983). A longitudinal assessment of consumer satisfaction/dissatisfaction: the dynamic aspect of the cognitive process. Journal of Marketing Research, 20(4), pp. 393-404.

Lee, E. L. (2015). Pictures speak louder than words: motivationds for using Instagram. 
Cyberpsychology, Behaviour, and Social Networking, Vol. 18 No. 9, pp. 552-556.

Leibowitz, B. (2017). Instagram vs Facebook: which can boost yor business more. Retrieved from Dreamgrow: www.dreamgrow.com/instagramfacebook-advertising

Leibowitz, B. (2018). Instagram vs Facebook: which can boost your business more. Retrieved from www.dreamgrow.com/instagramfacebook-advertising

Ling, K. P. (2010). The determinants of consumers' attitude towards the advertising effectiveness: Determinants and. Canadian social science, 6(14), 114-126.

Lingelbatch, D., Patino, A., \& Pitta, D. (2012). The emergence of marketing in millennial new ventures. Journal of Consumer Marketing, Vol. 29 No. 2, pp. 136-145.

Lorenzo-Romero. (2011). Consumer adoption of social networking sites: implications for theory and practice. Journal of Research in Interactive Marketing, Vol.5Nos2/3,pp.170-188.

Luarn, P. L. (2015). Influence of Facebook brand-page posts on online engagement. Online Information Review, , 39(4), 505519.

Mackenize, Lutz, S. (1989). An empirical examination of the structural antecedents of attitude toward the Ad in an advertising pretesting context. Journal of Marketing, 53(2), 48-65.

MacKenzie. (1989). An empirical examination of the structural antecedents of attitude toward the ad in an advertising pretesting context. The Journal of Marketing, 53, 4865.

MediaKix. (2018). The 2018 influencer marketing industry ad spend. Retrieved from http://mediakix.com/2018/03/influencermarketing-industry-ad-spendchart/\#gs.vpRbqRs
Metzger, M. \&. (2013). Credibility and trust of information in online environments: the use of cognitive heuristics. Journal of pragmatics , 210-220.

Mikalef, P. G. (2012). Exploring the business potential of social media: An utilitarian and hedonic motivation approach. BLED 2012 Proceedings, 21, p. 1-14.

Miles, J. (2014). Instagram power. Build your brand and reach more customers with the power of pictures. New York: McGrawHill Education.

Mitchell, A., \& Olson, J. (1981). Are product attribute beliefs the only mediator of advertising effects on brand attitudes. Journal of Marketing Research, Vol.18,August,pp. 318-31.

Moore, M. (2012). Interactive media usage among millennial cosumers. Journal of Consumer Marketing, Vol. 29 No. 6, pp. 436-444.

Murdough, C. (2009). Social media measuremnt; it's not impossible. Journal of Interactive Marketing, Vol. 10 No. 1, pp. 94-99.

Muscanell, N., \& Guadagno, R. (2012). Make new friends or keep the old; gender and personality differences in social networking use. Computers in Human Behaviour, Vol. 28, No. 1, pp. 107-112.

Neher. (2013). Social media marketing. Boot camp publishing.

Neher. (2013). Social media marketing. Harnessing images, Instagram, Inforgraphics and Pinterest to grow your business online.

Olney, T. H. (1991). Consumer responses to advertising: the effects of ad content, emotions, and attitude toward the ad on viewing time. Journal of Consumer Research, Vol. 17 No. 2, pp. 440-53.

Paerk, H. J. (2015). "How does visual merchandising in fashion retail stores affect consumers' brand attitude and purchase intention. The International Review of 
Retail, Distributionand Consumer Research, Vol.25No.1,pp.87-104. .

Pessala, I. (2016). User experiences and efficiency of Instagram advertising.

Pinho, J. S. (2011). Examining the technology acceptance model in the adoption of social networks. Journal of Research in Interactive Marketing, Vol. 5 No. 2, pp. 116-129.

Raji, R., Sabrina, M., Sobhi, M., \& Bahtiar, M. (2019). Do firm-created contents on social media enhance brand equity and consumer response among consumers of automotive brands. Journal of Promotion Management.

Rook, D. W. (1985). Consuming impulses. Advances in Consumer Research, 12, pp. 23-27.

Rushworth, D. a. (2017). Exploring the credibility of online celebrities' Instagram profiles in influencing the purchase decisions of young female users. Computers in human behaviour, Vol. 35 No. 6, pp. 823-835.

Saadeghvaziri, F. \&. (2011). Mobile advertising: An investigation of factors creating positive attitude in Iranian customers. African Journal of Business Management, 5(2), 394-404.

Saxena, A., \& Khanna, U. (2013). Advertising on social network sites; a structural equation modelling approach. Vision, Vol. 17 No. 1, pp. 17-25.

Schivinski, B. a. (2016). The effect of social media communication on consumer perceptionsofbrands",JournalofMarketing Communications,. Journal of Marketing Communications, Vol.22No.2,pp.189-214.

Seven Media Group. (2018). Sri lanka social media audience survey 2018. Retrieved from Seven Media Group: http://sevenmediagroup.co/sri-lankasocial-media-audience-survey-2018/

Sheldon, P. B. (2016). Instagram: motives for its use and relationship to narcissism and contextual age. Computers in human behaviour, Vol. 58, pp. 89-97.

Shim, S. (2013). The antecedents ofattitude toward IPTV advertising:the role of interactivity and advertising value. The Korean Journal of Advertising, Vol. 2 No. 1, pp.123-161.

Shu, W., \& Chuang, Y. (2011). The percevied benefits of six-degree-separation social networks. Internet Research, Vol. 21 No. 1, pp. 26-45.

Smith. (2017, November 6). 41 incredible Instagram statistics. Retrieved from www.brandwatch.com: www.brandwatch.com/blog/instagramstats

Sony Kusumasondjaja, F. T. (2018). Endorsement and visual complexity in food advertsing on Instagram. Emarald, 10662243.

Spreng, R. A. (1995). Service recovery: Impact on satisfaction and intentions. Journal of Services Marketing, 9(1),pp. 15-23.

Statista. (2016). Retrieved from www.statista.com:

https://www.statista.com/statistics/279776/ preferred-netizen-social-media-inindonesia-by-age/

Statista. (2018a, April 16). Distribution of Instagram users worldwide as of April 2018, by age and gender. Retrieved from www.statista.com: www.statista.com/statistics/248769/agedistribution-of-worldwide-instagramusers/

Stelzner, M. (2016, August 18). Retrieved from 2016

Stelzner, M. (2016). 2016 Social media marketing industry report, social media examiner. Retrieved from www.social media examinner.com: https://www.socialmediaexaminer.com/

Stelzner, M. (2016, May). social mdia marketing industry report. Retrieved from www.socialmediaexaminer.com: 
www.socialmediaexaminer.com/wpcontent/uploads/2016/05/SocialMediaMar ketingIndustryReport2016.pdf

Stern, B., \& Zaichowsky, J. L. (1991). The impact of'entertaining'advertising on consumer responses. Australian Marketing Researcher, , 14(1), 68-80.

Tafesse, W. (2015). Content strategies and audience response on Facebook brand pages. Marketing Intelligence \& Planning, , 33(6), 927-943.

Tariq, M. N. (2013). Customer perceptions about branding and purchase intention: a study of FMCG in an emerging market. Journal of Basic and Applied Scientific Research, Vol. 9572 No. 2, pp. 127-143.

Taylor. (2011). The informativeness of on-line advertising. International Journal of Industrial Organization, 29, 668-677.

Then, N. K. (1999). Apparel shopping on the web. Journal of Family and Consumer Sciences, 91(3), pp. 65-68.

Ting, H. W. (2015). Beliefs abot the use of Instagram: an exploratory study. International Journal of Business and Innovation, Vol. 2 No. 2, pp. 15-31.

Tsang, M. M. (2004). Consumer attitudes toward mobile advertising: An empirical study. International Journal of Electronic Commerce, , 8(3), 65-78.
Unala, S. \&. (2011). Attitude towards mobile advertising - A research to determine the differences between the attitude of youth and adults. . Procedia Social and Behavioural Sciences, 361-377.

Verma, I. (2014). Advertising credibility : A review of literature. Galaxy international interdisciplinary research journal, 189199.

Wang \& Sun, Y. (2010). Assesing beleifs, attitudes, and behavioural responses toward online advertsing in three ciuntries. International business review, 333-344.

Wang, S. \&. (2009). Examining beliefs and attitudes toward online advertising among Chinese consumers. Direct Marketing: An International Journal, Vol. 3 Issue: 1, pp.52-66.

Wilcox, K. a. (2013). Are close friends the enemy? Online social networks, selfesteem, and self-control. Journal of Consumer Research, Vol. 40 No. 1, pp. 90103.

Wirtz, B. a. (2016). Technology acceptance in social media: review, synthesis and directions for future empirical research. Journal of Electronic Commerce Research, Vol. 17 No. 2, pp. 97-115. 